\title{
Integration of ecolabelling and ecotourism schemes: Case study of forest honey in Indonesia
}

\author{
Andre Notohamijoyo ${ }^{1 *}$, Agil Abdul Hakim ${ }^{2}$, Mustaidz Billah ${ }^{3}$, and Adhi Setya \\ Wiyata $^{3}$ \\ ${ }^{1}$ Ministry of Tourism and Creative Economy, Jakarta, 10110, Indonesia \\ ${ }^{2}$ Ministry of Environment and Forestry, Jakarta, 10270, Indonesia \\ ${ }^{3}$ Ministry of Marine Affairs and Fisheries, Jakarta, 10110, Indonesia
}

\begin{abstract}
The growing level of public awareness of environmental sustainability increases understanding of environmentally friendly schemes such as ecolabeling. The community began to be moved to be involved in environmental conservation activities including the implementation of the ecolabel scheme. Likewise with Indonesia. Communities in several areas have been motivated to apply the selfdeclared forest honey ecolabel scheme. This encourages the preservation of nature around the forest area where the ecolabel scheme is implemented. However, there are still problems in implementing the ecolabel scheme, namely the welfare of the community. This requires more work from the Government. One of the things that the Government can more easily encourage to help improve the welfare of forest communities is by facilitating areas that implement an ecolabel scheme to become ecotourism destinations. In the post-Covid-19 virus pandemic like today, ecotourism is urgently needed and it is safer and more comfortable for tourists. This study reviews the model of integrating ecolabel schemes with ecotourism which will create a balance between environmental sustainability and community welfare. The research is based on a literacy study along with comparation with other countries. This is a tangible form of sustainable development.
\end{abstract}

\footnotetext{
* Corresponding author: andre.hamijoyo@gmail.com
} 


\section{Introduction}

The world economy experienced extraordinary shocks during the current Covid-19 virus pandemic, including Indonesia. The tourism sector is one of the sectors experiencing the heaviest shocks. Various tourist destinations are facing serious economic pressures such as the closure of tourist attractions, inns, lack of restaurants and souvenir shops to the cessation of transportation service operations.

When the pandemic hit, people were again attracted to traditional medicine to strengthen the immune system, such as honey, herbs and spices. Especially for honey, the demand for this commodity continues to increase and is very attractive to the public. Apart from its function as a food sweetener, honey provides health benefits and has been scientifically proven.

Honey is an important commodity that is of great interest to the public. The demand for honey continues to increase in line with the increase in population and public awareness of its benefits. Honey is not only seen as a sweetener, but also believed to provide health benefits that have been proven scientifically and traditionally (hereditary).

Honey in Indonesia is very diverse. The diversity of honey is influenced by differences in regional origin, season, types of bees, types of nectar sources, the way of life of bees (cultivated or wild), harvesting methods and post-harvest handling. Judging from the standard, honey is developed based on three categories, namely forest honey, cultivated honey and stingless bee honey (Trigona sp). Forest honey is a natural liquid which generally has a sweet taste produced by wild bees Apis dorsata (giant honey bee) and Apis sp from the extract of forest plants (floral nectar) or other parts of forest plants (extra floral).

The challenge in forest honey production is forest sustainability. Conservation efforts often face very serious threats, such as illegal logging, expansion of plantation land and others. Sustainability is often overlooked due to economic activities. These activities often occur due to the greed of big businessmen and do not have an impact on improving the welfare of the people living around the forest.

The government is trying to anticipate this condition by implementing an environmentally friendly ecolabel scheme. The government through the Ministry of Environment and Forestry (KLHK) actively encourages sustainable development through the implementation of an environmentally friendly ecolabel scheme as mandated by Law No.32 of 2009 concerning Environmental Protection and Management. The law was then followed up with the issuance of Minister of Environment Regulation No. 02/2014 concerning Ecolabeling Scheme.

Based on the Ministerial Regulation, there are 2 types of regulated logo inclusion, namely the Indonesian Ecolabel (Ekolabel Indonesia) logo for a product certification mark based on a multi-criteria ecolabel standard. The logo is a symbol of product life cycle from the raw material stage to the consumable stage (Figure 1). The other label is a self-declared Ecolabel (Ekolabel Swadeklarasi) logo for verification of selfdeclared claims. on some environmental parameters of a product declared by the manufacturer (Figure 2). 


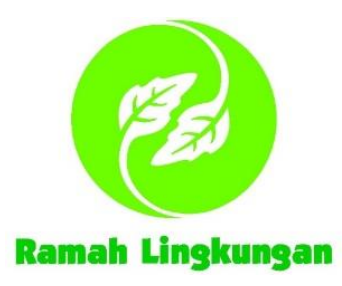

Fig 1. The Indonesian Ecolabel (Ekolabel Indonesia)

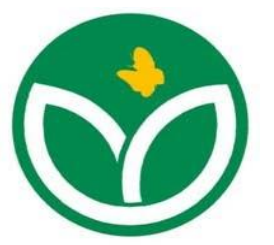

Fig 2. Self-declared Ecolabel (Ekolabel Swadeklarasi)

The assessment of suitability for forest honey is carried out through a self-declared ecolabel scheme with environmental claims for Panen Lestari. The claim is verified by a third party, namely the Ecolabel Verification Agency (LVE) of the Indonesian Forest Honey Network (JMHI). JMHI develops hygienic and sustainable forest honey harvest and post-harvest practices. On the other hand, the Ministry of Environment and Forestry is overseeing the ecolabel scheme with SNI 8664: 2018 standardization instruments for Honey (BSN: 2018). The ecolabel scheme and SNI for forest honey are expected to boost the quality and capacity of forest honey production.

Unfortunately, the production of forest honey which has received the ecolabel and SNI scheme has not been directly proportional to market access. The community still prioritizes the brands and packaging of honey products in the market so that forest honey still has difficulty competing.

Integrate forest honey ecolabel with ecotourism could be the solution. Ecotourism is a tourism concept that rests on the preservation of natural resources. Ecotourism offers tour packages that are based on natural beauty and a balance between social, economic and ecological aspects.

In various countries, ecotourism is integrated with the application of an ecolabel scheme. In Indonesia, the ecolabel scheme has only recently been formed, so it still takes time for the implementation process, including the readiness of the community to understand it. An in-depth and continuous study of the implementation of the ecolabel scheme is needed, including the process of integration with ecotourism. Indonesia can start to try this integration, of course, by adjusting the characteristics of the culture and the prevailing system. 


\section{Method}

The study analyst the model of the integration with studies on village-own enterprises (BUM Desa). The model integrate the role of each ministry to the community of village through BUM Desa. The model will be the key role of success of integration process.

This next step is focus on literature on the integration of ecolabel and ecotourism in various regions of the world. The comparison between various countries will be a basis for the integration between ecolabel and ecotourism in Indonesia. This research is hoped to be able to dig up more information regarding the integration of ecolabeling and ecotourism so that it can be applied in Indonesia.

\section{Result and Discussion}

The role of the Government in supporting the integration of ecolabel and ecotourism is very important. This is necessary to support the improvement of the welfare of the people living around the forest. It needs a balance between the welfare of the community in the location around the forest and its sustainability.

This is where the need for support from the Government for improving the welfare of the community. Support from both central and local government must be well consolidated. Collaboration between Government agencies is needed to be able to optimize the benefits of this support. The community must also get non-financial support from the Government to manage assistance from the Government. This assistance must be managed properly by the community.

The government can facilitate forest honey cultivation areas with various facilities that can be utilized by communities around the forest. Facilities such as basic infrastructure, guest houses, canteens, showrooms can be provided to communities around the forest. Basic infrastructure is the responsibility of the Ministry of Public Works and Public Housing (Kementerian PUPR). Infrastructure improvements in the forest honey ecolabel management area are needed to facilitate access for tourists coming to ecotourism locations.

Apart from infrastructure, another thing needed is the facilitation of tourism facilities such as lodging, showrooms, food courts and others. The Government Assistance Program (Banper) for facilities from the Ministry of Tourism and Creative Economy (Kemenparekraf) can be a solution.

Capacity Building Assistance from the Ministry of Villages, Disadvantaged Areas and Transmigration also needed to assist the forest communities. The assistance could support the communities to increase the capacity and capability to manage the support from government. The common problem usually found in community to handle the government support is regarding the management capacity.

Forest communities should be encouraged to form a special organization that manages government facilities. The community can form Village-Owned Enterprises 
(BUM Desa). This management can encourage an increase in the role and income of residents/village communities around the forest area.

The formation of Village-Owned Enterprises (Badan Usaha Milik Desa/BUM Desa) is very suitable to be applied to communities around forests. Training for the community on the management of village-owned enterprises will increase the capacity and capability of the community in managing the facilities provided by the Government. The assistance that can be provided by the Government in terms of basic infrastructure, supporting infrastructure (lodging, honey storage rooms, showrooms, etc.), training, capacity building and others can be managed by BUM Desa. The income obtained from BUM Desa must be managed properly to help improve the welfare of the community and to maintain the various facilities provided by the Government.

Village-owned enterprises have been regulated in the laws and regulations in Indonesia. One of them is Law of The Republic of Indonesia No. 6 of 2014 concerning Village. Article 87 of the regulation states that Villages can establish Village-Owned Enterprises called BUM Desa. BUM Desa is managed with a family spirit and mutual cooperation. BUM Desa can run a business in the economic sector and / or public services in accordance with the provisions of laws and regulations.

The derivative regulation of the aforementioned Law is Government Regulation of The Republic of Indonesia No. 43 of 2014 concerning Regulation for Implementing Law No. 6 of 2014 concerning Village. Article 1 paragraph 7 of the regulation states that "Village-Owned Enterprises, hereinafter referred to as Village BUM, are business entities whose entire or most of their capital is owned by the Village through direct participation originating from separated Village assets to manage assets, services, and other efforts for the maximum welfare of the Village community." This becomes the basis for the Government in managing the village economy.

It is hoped that the development of BUM Desa can also improve the welfare of the community around the forest. BUM Desa will also be a bridge between government assistance and sustainable development in forest honey areas. The role of BUM Desa is very strategic in forest conservation, community welfare and the harmony of village communities around the forest.

There are four government institution related to the role of BUM Desa. The institutions are:

a. Ministry of Public Workds and Public Housing for basic infrastructure assistance

b. Ministry of Tourism and Creative Economy fot facilities assistance, especially for tourism

c. Ministry of Villages, Disadvantaged Areas and Transmigration for capacity building

d. Ministry of Environment and Forestry for monitoring and evaluation 
The following is a model for managing assistance provided by the Government:

Table 1. Management Model of Government Assistance by BUM Desa

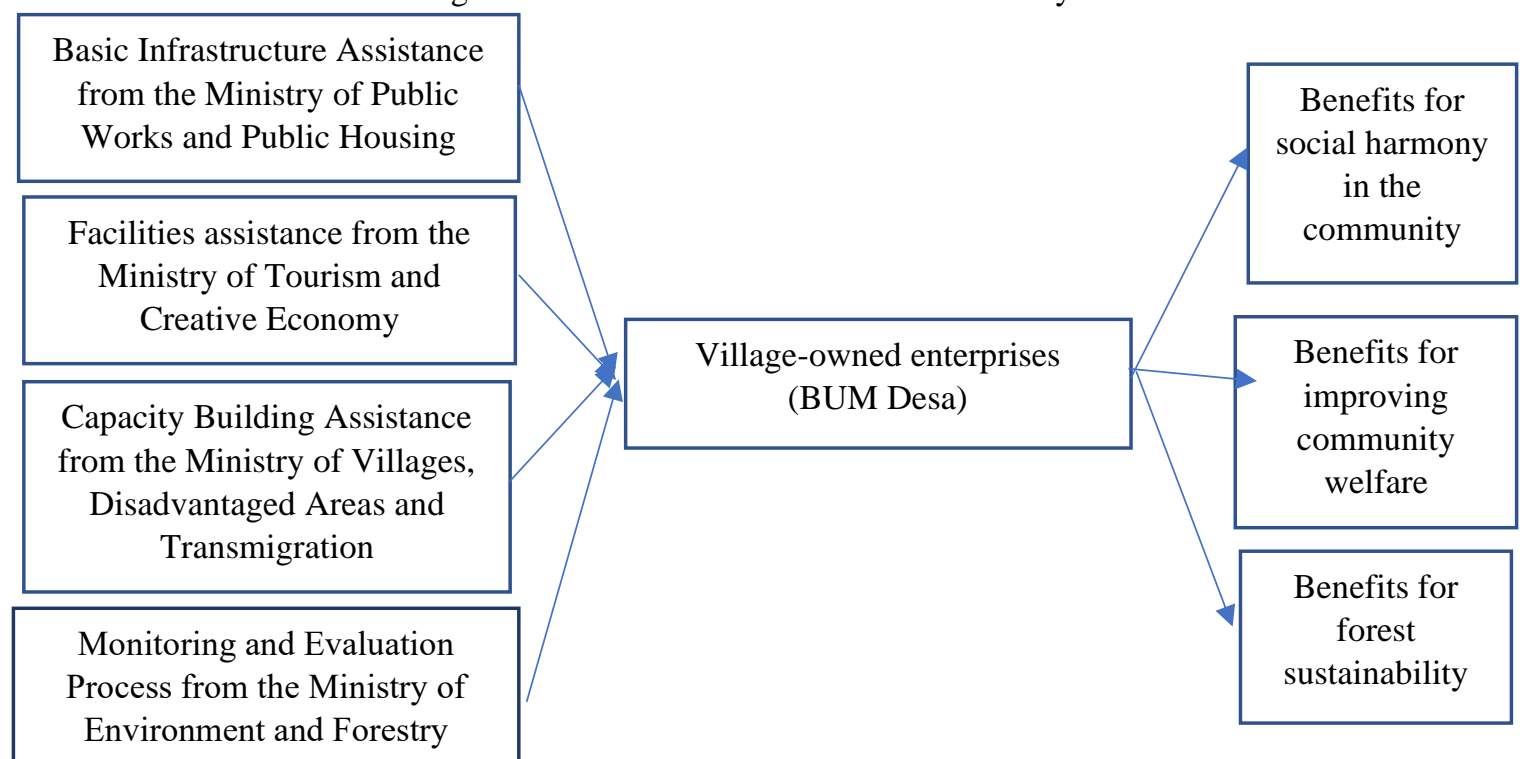

Based on this model, it can be seen that if various Government assistance can be consolidated in one institution, it is hoped that the benefits obtained by the community can be felt more thoroughly. Benefits for improving welfare, social harmony and forest sustainability can be achieved optimally. This model needs to be developed in various Forest Honey Areas such as West Kalimantan.

The integration between ecotourism and ecolabeling can increase local income and play a role in encouraging economic development in the natural tourism area in a significant and sustainable manner. Ecotourism is also the answer to the problem of declining tourists during the Covid-19 Pandemic as it is today. Travel in the open is a great option for avoiding close human contact. Of course, the tourist destination must still apply strict health protocols.

Barham (2002) states in his research that Convention theory provides guidelines on how to analyze values-based labeling as a new tool that unites production and consumption as a single unit along with moral values in it. Values-based labeling is a social movement that encourages production and consumption along with moral responsibility for environmental sustainability, resource preservation and fulfillment of community rights in resource exploitation

Research from Fairweather et al. (2005) conducted on tourists in Christchurch, New Zealand shows that only $13 \%$ of tourists have heard of ecolabel tourism. Meanwhile, only 33\% understand ecolabel. Nonetheless Most respondents support biocentric values and like the development of ecolabels in New Zealand. Respondents also expressed support for ecolabel certification for accommodation. 
Rex and Bauman (2007) stated that ecolabel product marketing must adopt conventional marketing principles in order to be more widely accepted by society instead of just trying to encourage the use of labels.

Sonderskov and Daubjerg (2010) in a study of consumers in the US, UK, Denmark and Sweden proved that ecolabelling can be successful with substantial support or full government support in all stages. The level of consumer confidence in ecolabel products increases with the intense involvement of the government.

Research from Barham (2002), Fairweather et.al (2005), Rex and Bauman (2007) and Sonderskov and Daubjerg (2010) show that ecolabel schemes require strong support from the government and also adapt to conventional market conditions. The development of ecolabel is related to the development of public understanding of the importance of preserving natural resources and the environment. Not only promotion is carried out in encouraging the optimization of the implementation of the ecolabel scheme but also education of public awareness of the importance of preserving natural resources and the environment. Awareness building is also important for the development of ecotourism. Several studies have shown the importance of building this awareness in society.

Research from Haesup Han et al. (2019) in Korea shows that community-based tourism is an efficient means of increasing social sustainability, preserving local traditions, natural resources and reducing poverty. This research proves that local wisdom can be of good value to improve tourism performance and provide new experiences for tourists.

Research from Tagoranao and Gamon (2019) in Phillipines shows that the presence of wellformulated policies and guidelines on ecotourism in adapting the climate change will widen the possibilities for the people to further benefit from ecotourism development. In conclusion, it is of great importance that in facing the climate changes, the government must have strict environmental standards compounded by strict enforcement.

Research from Kurniawati et al. (2020) in Tulungagung, East Java, Indonesia, show that community participation is very necessary in maintaining environmental sustainability and local cultural wisdom. This study recommends that tourism managers, both government, private and community, could integrate local traditions because they are an important part of the sustainable ecotourism. In addition to providing new job opportunities, involving local communities in ecotourism management can maintain local traditions that contain the noble values of their predecessors.

The study of Walter et al. (2018) in Nepal show that lessons are needed for local people to understand tourism and adapt it to local culture. This learning is needed to accompany the growth of tourism businesses such as the homestay business, internet marketing, to increase a good work culture.

Research from Kim et al. (2019) in Cambodia shows that increasing the capacity of local communities is needed to develop tourism. Tourism based on local wisdom and environmental sustainability can play a major role in the transformation of the local economy. In addition, this transformation will encourage the growth of ecotourism that is based on local wisdom, environmental sustainability and community welfare. 
Research from Phelan et al. (2020) in South Sulawesi, Indonesia shows that ecotourism plays an important role in supporting the preservation of culture, nature and improving people's welfare. There are three main things that people need in developing ecotourism, namely waste management, hospitality management skills, and marketing. This is where the need for integration between the community with local economic development and environmental preservation.

Research carried out in various countries shows that the approach to local communities is the most important thing in ecotourism. The community has an important role in the sustainable management of an area. Even so, we need a standardization of ecotourism in an area. This standardization will determine a quality management system. Such management must prioritize the principles of sustainable development and be adapted to local culture.

Research from Medina (2005) states that there is a need for advocacy for certification with standards measuring compliance with the dimensions of the definition of ecotourism that are widely accepted. In addition, the certification must provide benefits for local communities. The eco-tourism standard must go through a process of harmonization or standardization of certification criteria. The success of the certification process can affect the benefits of ecotourism for local communities.

Research from Medina shows that standardization is needed to strengthen ecotourism. Apart from standardization, another thing that is needed is how to encourage the benefits of ecotourism for the local population. The continuity between these standards and benefits is the key to the success of ecotourism in a region. This is very important for the integration process between ecolabel and ecotourism.

Several forest honey locations in Indonesia such as Betung Kerihun and Lake Sentaru National Park, West Kalimantan or Desa Pempatan, Rendang District, Karangasem Regency, Bali can become pilot projects for ecolabel and ecotourism integration. Local cultural wisdom and the readiness of the community to receive outside guests are good assets for the development of ecotourism.

The community can also take advantage of village funds from the Ministry of Villages, Disadvantaged Areas and Transmigration (Kemdes) to optimize the integration of ecolabeling and ecotourism. Several success stories of village funds can be duplicated, such as Umbul Ponggok Village, Klaten, Central Java, which has successfully built a natural pool to become a leading tourism integrated with culinary centers, craft shops, guest houses to seminar venues. This is where there is a need for synergy between various stakeholders both at the central and regional levels to rebuild the tourism sector at a time of adapting to new normal like today through the integration of ecolabelling and ecotourism.

\section{Conclusion}

Integration of Ecolabel and Ecotourism needs to be built through the synergy between the Government and communities in forest areas. The application of the ecolabel forest honey needs to be accompanied by the application of ecotourism. 
The application of ecotourism is encouraged through the facilitation provided by the Government to forest area communities through Village-Owned Enterprises (BUM Desa). The success of implementing ecotourism through BUM Desa is a form of integration between ecolabel and ecotourism.

It is also a form of collaboration between various government agencies. This is a challenge for the Government of Indonesia to make it happen.

The government must make an approach to the community in the village around the forest which is an ecolabel area. This approach to the community is needed to raise awareness of the importance of implementing ecolabels for the preservation of forest resources as well as building the regional economy. Increasing the capacity and capability of the community in managing forest areas will encourage better community capacity building in implementing ecotourism. Government intervention is urgently needed in the integration process between ekolabel dan ekowisata. The integration will improve the welfare of the people around the area.

\section{References}

1. Barham, Elizabeth. Towards a theory of values-based labeling. Agriculture and Human Values. 19, 349-360 (2002)

2. Fairweather, John, R., Maslin, Crystal \& Simmons, David, G. Environmental Values and Response to Ecolabels Among International Visitors to New Zealand, Journal of Sustainable Tourism, 13:1, 82-98 (2005)

3. Government Regulation of The Republic of Indonesia No. 43 of 2014 concerning Regulation for Implementing Law No. 6 of 2014 concerning Village

4. Han, Haesup, Eom, Taeyeon, Al-Ansi, Amr, Ryu, Hyungseo, Bobby \& Kim, Wansoo. Community-based tourism as a sustainable direction in destination development: an empirical examination of visitor behaviors. Sustainability, 11(10), 28-64 (2019)

5. Kim, Marin., Xie, Yi, \& Cirella, Giuseppe, T. Sustainable transformative economy: community-based ecotourism. Sustainability, 11(18), 49-77 (2019)

6. Kurniawati, Elya, Sumarmi, Sumarmi. and Aliman, Muhammad. Participation of Green Environmental Group and Ulur-ulur Local Wisdom on Buret Lake Ecotourism Management in Karst Area of Tulungagung, Indonesia. Geo Journal of Tourism and Geosites, 30, 889-895 (2020)

7. Laporan Kinerja Bidang Pertanian, Pangan dan Kesehatan 2018. Pusat Perumusan Standar. Deputi Bidang Penelitian dan Kerjasama Standardisasi. Badan Standardisasi Nasional

8. Law of The Republic of Indonesia No. 32 of 2009 concerning Management and Protection of The Environment

9. Law of The Republic of Indonesia No. 6 of 2014 concerning Village

10. Medina, Laurie, Kroshus. Ecotourism and Certification: Confronting the Principles and Pragmatics of Socially Responsible Tourism, Journal of Sustainable Tourism, 13:3, 281-295 (2005) 
11. Minister of Environment Regulation No. 02/2014 concerning Ecolabeling Scheme

12. Phelan, Anna (Anya), Ruhanen, Lisa, \& Mair, Judith. Ecosystem services approach for community-based ecotourism: towards an equitable and sustainable blue economy. Journal of Sustainable Tourism, 1-21 (2020)

13. Rex, Emma, Baumann, Henrikke. Beyond ecolabels: what green marketing can learn from conventional marketing. Journal of Cleaner Production. 15, 567576 (2007)

14. Standar Nasional Indonesia (SNI) 8664:2018 Madu

15. Sonderskov, Kim Mannemar, Daubjerg, Carsten. Ecolabelling, the state and consumer confidence. Political Studies Association Annual Conference (2010)

16. Tagoranao, Mariam Saidona and Gamon, Alizanan, Dumangcaq. Relevance of Philippine policies for muslim-friendly ecotourism management in adapting the climate change challenges. In IOP Conference Series: Earth and Environmental Science (Vol. 348, No. 1, p. 012012). IOP Publishing (2019)

17. Walter, Pierre, Regmi, Kapil, Dev, and Khanal, Pushpa, Raj. Host learning in community-based ecotourism in Nepal: The case of Sirubari and Ghalegaun homestays. Tourism management perspectives, 26, 49-58 (2018) 